\title{
Neurons Responding to Whole-Body Motion in the Primate Hippocampus
}

\author{
Shane M. O'Mara, ${ }^{a}$ Edmund T. Rolls, A. Berthoz, ${ }^{b}$ and R. P. Kesner ${ }^{c}$ \\ University of Oxford, Department of Experimental Psychology, Oxford, OX1 3UD, United Kingdom
}

\begin{abstract}
We describe here hippocampal cells that respond during whole-body motion when a monkey is moved on a remotecontrolled robot-mounted platform in a cue-controlled test chamber $(2 \times 2 \times 2 \mathrm{~m})$. Some of these cells responded to linear motion, and others to axial rotation. Some of these cells responded when the same motion occurred without a view of the visual field. Such cells appeared to be driven by vestibular inputs. Other cells required a view of the visual field for their response, and these cells appeared to be driven by the visual motion relative to the monkey of the test chamber. Further evidence that this was the case was that some of the cells responded to rotation and linear motion of the test chamber while the monkey remained stationary. Other cells responded to combinations of whole-body motion and a view of the environment.

These findings show that information about whole-body motion, as well as about where the animal is looking in an environment, is represented in the primate hippocampus. We suggest that this information is important in spatial memory and thus in spatial navigation.
\end{abstract}

[Key words: hippocampus, vestlbular system, memory, navigation, place, space]

Bilateral damage to the temporal lobe in humans can cause anterograde amnesia (Scoville and Milner, 1957; Milner, 1972). A number of cortical and subcortical areas are affected, including structures of the hippocampal formation (Squire, 1992). In analyses of the way in which the hippocampus could contribute to a memory deficit in primates (for review, see Rolls, 1990), it has been shown that tasks that are particularly affected by damage to the hippocampus or fornix in the primate include spatial tasks such as memory of where in space an object has been seen before (Smith and Milner, 1981; Gaffan and Saunders, 1985; Parkinson et al., 1988), use of spatial cues to determine which object to select for reward in spatial memory tasks (Gaffan and

\footnotetext{
Received Jan. 26, 1994; revised Apr. 22, 1994; accepted Apr. 27, 1994.

This research was supported by Medical Research Council Grant PG8513790 and by the Oxford McDonnell-Pew Centre in Cognitive Neuroscience. A.B. was a Visiting Professor at the Oxford McDonnell-Pew Centre in Cognitive Neuroscience, and received support from the Programme CogniScience of CNRS

Correspondence should be addressed to Dr. E. T. Rolls, University of Oxford, Department of Experimental Psychology, South Parks Road, Oxford, OX1 3UD, UK.

aPresent address: Department of Physiology, University of Dublin, Trinity College, Dublin 2, Ireland.

'Present address: College de France/CNRS, 15, Rue de L'Ecole de Medicine, 75270 Paris, France.

'Present address: Department of Psychology, University of Utah, Salt Lake City, UT 84112.

Copyright (C) 1994 Society for Neuroscience $0270-6474 / 94 / 146511-13 \$ 05.00 / 0$
}

Harrison, 1988), and learning where to make a spatial response (Gaffan et al., 1984a,b; Rupniak and Gaffan, 1987; and in human, Petrides, 1985). In analyses of the functions of the hippocampus in the rat, it has been suggested that rats with hippocampal damage have an impaired ability to create a map of space, in that they are impaired in running correctly on an eightarm maze, or in swimming correctly to a submerged platform, that is, situations in which extramaze cues must be used to determine their position in space (O'Keefe and Nadel, 1978; Morris et al., 1982; Barnes, 1988). There is also evidence in the rat that some hippocampal neurons fire when the rat is in a particular place in an environment (O'Keefe, 1979; McNaughton et al., 1983); such cells have been named "place" cells (O'Keefe and Nadel, 1978).

In order to analyze neurophysiologically how the primate hippocampus may be involved in spatial function, and in particular in memory for where in space objects had been seen before (see above), Rolls et al. (1989) recorded the responses of hippocampal neurons in macaques using a serial multiple object-place memory task requiring a memory for which of four or nine positions on a video monitor a given object had appeared in previously (this task is known to be impaired by fornix section; Gaffan and Saunders, 1985). It was found that $9.3 \%$ of neurons recorded in the hippocampus and parahippocampal gyrus had spatial fields in this and related tasks; $2.4 \%$ of the neurons responded to a combination of spatial information and information about the object seen (i.e., they responded more the first time a particular object was seen in any position). This investigation showed that not only is spatial information processed by the primate hippocampus, but it can be combined with information about which stimuli have been seen previously (Rolls et al., 1989). These "space" neurons (Cahusac et al., 1989; Rolls et al., 1989) may be compared with place cells recorded in the rat hippocampus (see O'Keefe, 1979; McNaughton et al., 1983). "Place" cells respond when the rat is in a particular place in the environment as specified by extramaze cues, whereas the "space" cells described here respond when the monkey looks at particular positions in space, or when stimuli are shown in particular positions in space (see further Feigenbaum and Rolls, 1991).

These studies showed that some hippocampal neurons in primates have spatial fields. Feigenbaum and Rolls (1991) investigated whether the spatial fields of hippocampal neurons use egocentric or some form of allocentric coordinates. This was examined by finding a neuron with a space field, and then moving the monitor screen and the monkey, relative to cach other and to different positions in the laboratory. The responses of $10 \%$ of the spatial units remained in the same position relative to the monkey's body axis when the screen was moved or the 
monkey was rotated or moved to a different position in the laboratory. These neurons thus represented space in egocentric coordinates. For $46 \%$ of the spatial neurons analyzed, the responses remained in the same position on the screcn or in the room when the monkey was rotated or moved to a different position in the laboratory. These neurons thus represented space in allocentric coordinates, that is, independently of the monkey's own body axis. These results provide evidence that in addition to neurons with egocentric spatial fields, which have also been found in other parts of the brain (Sakata, 1985; Andersen, 1987), there are neurons in the primate hippocampal formation that encode space in allocentric coordinates (see also Tamura et al., 1990, 1992a,b).

In studies of spatial navigation, it has been shown that cats and dogs (Beritoff, 1965), hamsters (Etienne et al., 1988), gerbils (Mittelstaedt and Mittelstaedt, 1982), rats (Miller et al., 1983), and humans (Beritoff, 1963; Mittelstaedt and Glasauer, 1991) actively and passively displaced from an initial location in the dark can return to this location, and therefore they use inertial or proprioceptive (idiothetic) cues to update visual spatial memory. Experimental evidence of a specific disturbance of homing or "path integration" by lesions of the labyrinth has been reviewed by Potegal (1982), who explicitly suggested a contribution of vestibular information for short-term navigation. Further evidence for such a contribution was obtained by Etienne et al. (1988) for rotations but not for linear translation. The ability to navigate in this way implies the need for a nonvisual memory for body motion and orientation based on signals originating from the vestibular and other nonvisual sensory systems. This provides part of the background for the present study, in which we investigate whether there are cells in the primate hippocampus, as it is a brain region implicated in memory, which respond to whole-body motion.

In present experiments (Rolls and O'Mara, 1993) we are analyzing the distinction between different types of spatial cell in the primate hippocampus by investigating the responses of hippocampal cells when macaques are moved in a small chair or robot on wheels in a cue-controlled testing environment (a $2 \times$ $2 \times 2$ m chamber with matte black internal walls and floors). One type of spatial cell found in this environment responds whenever the monkey is looking at one subarea of the environment, irrespective of the place where he is in the environment (Rolls and O'Mara, 1993). These we call "view" cells. Another type of cell found responds to movement of the monkey through space, and this type of cell is described here. The cells that responded to movement were named whole-body motion cells because they responded only to translation of the monkey through space and/or to rotation of the monkey in space. Cells of this type have not been described before in nonhuman primates or in studies of rats; this paper appears to be the first description of neurons with activity related to whole-body motion in the hippocampus.

Preliminary reports of this work have appeared in abstract form (O'Mara et al., 1991, 1992a-c; Rolls and O'Mara, 1991).

\section{Materials and Methods}

\section{Testing environment}

The cue-controlled rotatable test chamber $2 \times 2 \times 2 \mathrm{~m}$ high used for these experiments is shown in Figure 1. The enclosure was high enough so that the monkey could not see out, as described below. The chamber was matte black inside, and testing was normally performed with the matte black door closed. The walls could be rotated, or translated $1 \mathrm{~m}$, while the floor remained fixed. The chamber was evenly illuminated by artificial light to a level of 520 lux, a normal level for room illumination. The testing was generally conducted under normal light and sometimes in complete darkness, as described below. There was a set of four distinctive cues (a white cross, triangle, circle, and rectangle) placed on the walls of the chamber, as shown in Figure 1, to provide a spatial reference frame for the monkey. Each cue was approximately $30 \mathrm{~cm}$ in diameter. To encourage the monkey to use these cues to define the space in the test chamber, one gray plastic cup, $4 \times 4 \times 4 \mathrm{~cm}$, was placed on each wall, as shown in Figure 1. Each of three cups contained a different food (peanut, banana chip, apple chip), which was always in the same position in the test chamber as defined by the four spatial reference cues. The cups were at eye height so that the monkey could not scc inside, but he could reach into a cup to obtain a piece of the food it contained. The cup on wall 3 of the test chamber never contained food.

\section{Test chair and robot}

The monkey sat in a test chair $65 \mathrm{~cm}$ high that could either be placed on a trolley on wheels so that the experimenter could move the monkey, or could be placed on a robot so that the monkey could be moved with precisely defined accelerations and velocities. The robot was $55 \mathrm{~cm}$ in diameter and $45 \mathrm{~cm}$ high (Robosoft S.A., Neuilly-Plaisance, France). It was controlled by an IBM-PC computer, and we could make it rotate under program control with angular velocities in the range of $0-100 \%$ $\mathrm{sec}$, and translate forward or backward with velocities of $50-200 \mathrm{~m} / \mathrm{sec}$. The velocity profiles consisted of a ramp-step-ramp sequence in order to obtain a smooth acceleration and deceleration (see Fig. 10i, bottom, which illustrates the standard velocity profile used for linear translation). The values of the acceleration and deceleration used were in the range of $20-45 \% \mathrm{sec} / \mathrm{sec}$ and $100-300 \mathrm{~m} / \mathrm{sec} / \mathrm{sec}$. These values are well above the vestibular thresholds for both angular and linear movement detection. The duration of the linear motion was also within the time it takes for humans to detect the acceleration (Young, 1984). The monkey's chair was on a turntable, so that the forward and backward translation of the robot could be used to produce linear motion in any direction with respect to the monkey's body axis. The monkey's view of the test environment was that allowed by eye movement: his head was recessed $25 \mathrm{~cm}$ inside the test chair and his view was restricted laterally to an angle of $100^{\circ}$ by the sides of the chair, and to $25^{\circ}$ vertically by the top of the chair so that he could not see above the walls of the test chamber.

\section{Test procedure}

In all cases the firing rate of the cell was measured in a $2-4 \mathrm{sec}$ period before any movement started, and the firing rate was also measured during the $1-5$ sec period in which the movement occurred. Each test was repeated at least four times, and during the application of the different tests, retests were performed where possible to check for consistency of the cell's responses. As many as possible of the appropriate tests for a given cell were performed while recordings were made from a single cell, which was typically possible for $0.3-3 \mathrm{hr}$. In all the tests described here, the monkey was moved by the experimenter or the robot. The following tests were applied to any cell that responded in relation to any whole-body movement.

Linear translation. The monkey was moved forward, backward, left, and right in a straight line for distances of $2 \mathrm{~m}$ at a standard velocity of $0.2 \mathrm{~m} / \mathrm{sec}$. The standard start position was with the monkey's back to the door. If a cell responded in relation to any of the movements, then the movement was generally repeated with the monkey facing in a different direction in the test chamber, and sometimes with the monkey in different places in the test chamber or with a mask placed on the chair to occlude the monkey's view of the environment (see Occlusion of the visual field during whole-body motion, below). These tests allowed examination of whether a cell responded in relation to movement alone, or whether the response was related also to the view the monkey had during the movement (including the possibility that neurons may respond during movement toward or away from a particular place), or to which place in the chamber the monkey was during the movement.

Rotation. The monkey was rotated clockwise or counterclockwise about the vertical head/body axis for angles of $45-360^{\circ}$ at a velocity of $45 \% \mathrm{sec}$. As for translation, responsive cells were sometimes tested with the monkey in different starting orientations and places in the test chamber, or with a mask placed on the chair to occlude the monkey's view of the environment (see Occlusion of the visual field during wholc-body motion, below). 


\section{Rotatable and Translatable Cue-Controlled Test Chamber}

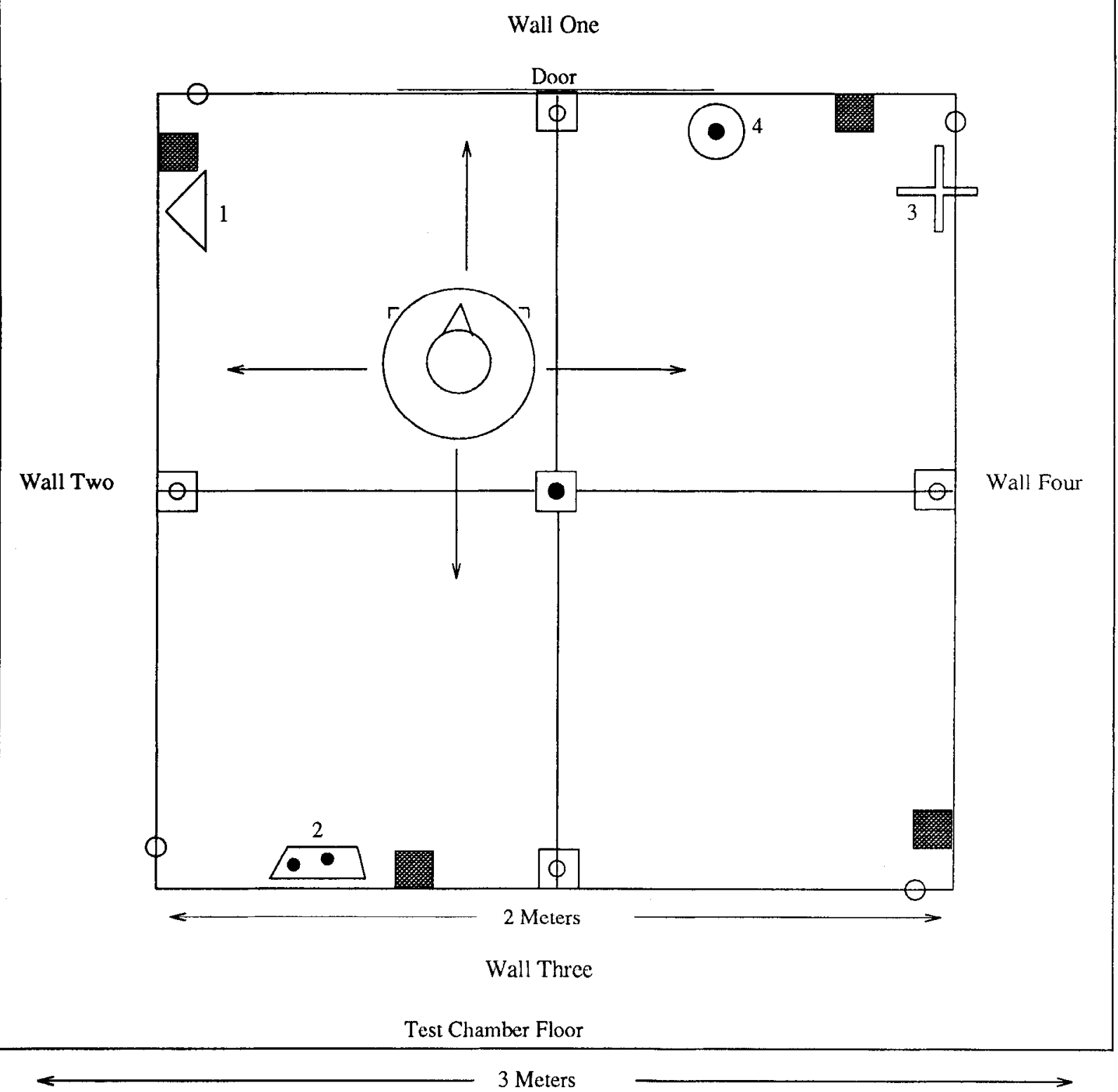

The circle, square etc. marked 1-4 are cue cards.

The squares with the inlaid circle represent the touch pads mounted on each wall of the test chamber.

The LED's were mounted $10 \mathrm{~cm}$ above the touch pads.

The shaded squares represent the food cups.

Figure 1. The $2 \times 2 \times 2 \mathrm{~m}$ cue-controlled rotatable and translatable test chamber, shown in plan view.

Rotation and translation of the test chamber. The testing chamber could be rotated and translated about its center point as described above. When cells were found that responded to whole-body motion, the contributions of vestibular and proprioceptive cues compared to visual motion cues to the response of the cell could be compared by translation and rotation of the test chamber. Visual motion cues similar to those induced by whole-body motion were induced by translating or rotating the walls of the test chamber, while the monkey's chair remained stationary in the test chamber. The walls were moved with velocities and over time periods that were similar to those induced by the whole-body movements described above.

Occlusion of the visual field during whole-body motion. A complementary test to those described was to rotate or translate the monkey in the test chamber with the monkey's view of the test chamber com- 


\begin{tabular}{lccc}
\hline Table 1. Summary of cell types/numbers of cells & & \\
& Total & \% Increase & \% Decrease \\
\hline Total number of cells tested & 461 & & \\
Total number showing motion-related responding & $45(9.8 \%)$ & & \\
Axial rotation only & 13 & 247 & 55 \\
Linear translation only & 9 & 282 & 53 \\
Axial rotation and linear translation & 20 & 320 & - \\
Room rotation only & 1 & 640 & - \\
Combination of view or place and motion & 3 & 409 & \\
Total & $46(9.9 \%)$ & & \\
\hline
\end{tabular}

pletely obscured by an opaque screen fitted to the front of the test chair and with the lights turned out. This controls for any dependence on visual input in the response of a cell, and therefore indicates if a cell is responding primarily to visual or vestibular inputs.

\section{Recording techniques}

The activity of single neurons was recorded with glass-insulated tungsten microelectrodes (after Merrill and Ainsworth, 1972, but without the platinum plating) in four macaque monkeys (Macaca mulatta) (weight $2.5-3.5 \mathrm{~kg}$, aged 1-2 years) seated in a primate chair using techniques that have been described previously (Rolls et al., 1976). The monkeys had been implanted under thiopentone sodium anesthesia with a stainless steel holder that supported the head facing directly forward during experiments and that also supported the microdrive in the subsequent daily recording sessions. They were pretreated with ketamine $(0.1 \mathrm{ml} /$ $\mathrm{kg}$ ) and posttreated with the analgesic buprenorphine (Temgesic; 0.2 $\mathrm{ml} / \mathrm{kg}$ ) and the antibiotic amoxycillin (Cynulox; $0.1 \mathrm{ml} / \mathrm{kg} / \mathrm{d}$ for $5 \mathrm{~d}$ ). The action potentials of single cells were amplified using techniques described previously (Rolls et al., 1979), converted into digital pulses using the trigger circuit of an oscilloscope, and analyzed on line using a Microvax II computer or IBM-PC. We ensured that recordings were from only a single cell by continuously monitoring the interspike interval to make sure that intervals of less than $2 \mathrm{msec}$ were not seen, and by continuously monitoring the waveform of the recorded action potentials. When testing was performed with the movements being performed by the robot, the computer collected perimovement rastergrams of neuronal activity for each trial and displayed, printed, and stored the data for each trial. The rastergrams started 1 sec before the movement started, and continued for $4 \mathrm{sec}$ after the start of the movement. When testing was performed by the experimenter moving the chair, the computer measured the firing rate of the neuron and its standard deviation based on $0.5 \mathrm{sec}$ samples during periods selected by the experimenter that corresponded to one of the movements (e.g., during a $4 \mathrm{sec}$ whole-body motion forward) or to a preceding control period. The period within which the firing rate was measured included the short (typically $0.5 \mathrm{sec}$ ) acceleration phase, the steady velocity phase (typically $3 \mathrm{sec}$ ), and the deceleration phase (typically $0.5 \mathrm{sec}$ ).

$\mathrm{X}$-radiographs taken in the coronal and parasagittal planes were used to locate the position of the microelectrode on each recording track relative to permanently implanted reference electrodes and bony landmarks such as the posterior tip of the sphenoid bone (Aggleton and Passingham, 1981). At the time of histology, the animals were narcotized with ketamine, deeply anesthetized with intravenous pentobarbitone sodium, and perfused with normal saline followed by $10 \%$ formal saline. Sharpened hollow tubes (diameter $=1.5 \mathrm{~mm}$ ) were passed stereotaxically through the brain parallel to the intra-aural/inferior orbital plane to provide a dorsoventral reference point between sections. The position of cells was reconstructed from the $x$-ray coordinates taken together with serial $50 \mu \mathrm{m}$ histological sections in the coronal plane stained with cresyl violet, which showed the reference electrodes and microlesions made at the end of some of the microelectrode tracks (see Feigenbaum and Rolls, 1991, for full details).

\section{Statistical analysis}

Between four and 10 measurements of the firing rate in each condition were obtained. A one-way analysis of variance was then performed, to determine whether there were significant differences between conditions.
Provided that this was significant (at the 0.05 level at least, though for the majority of the cells this was $<0.001$ ), the conditions that were significantly different from each other were then determined with post hoc Tukcy test analysis. The critcrion for a movement-related cell was that it responded significantly differently to at least one of the wholebody movement conditions compared to the stationary condition. Control tests were also performed to ensure that the neuron did not respond when the monkey was stationary but was aroused, by for example touch to the leg or reaching for food.

\section{Results}

\section{Electrophysiological characteristics of whole-body motion neurons}

Four hundred and sixty-one cells were recorded, of which 45 $(9.8 \%)$ responded to whole-body motion. The mean firing rate of cells that responded by increasing their rate of firing was 12.9 $(\mathrm{SE} \pm 1.8) \mathrm{spikes} / \mathrm{sec}$, and their responses increased to a mean of 30.9 (SE \pm 3.4 ) spikes/sec (an increase to $240 \%$ of the spontaneous rate). The mean firing rate of cells that responded by decreasing their rate of firing was 13.4 (SE \pm 1.8 ), and their responses decreased to a mean of 7.3 ( $\mathrm{SE} \pm 1.3$ ) spikes/sec (a decrease to $54 \%$ ). The lowest recorded spontaneous firing rate of a responsive cell was 0.4 spikes/sec, and the highest spontaneous firing rate of a responsive cell was 48 spikes/sec. The highest evoked firing rate was 93.3 spikes/sec. A summary of the numbers of different types of cells recorded is provided in Table 1. The properties of these types of neuronal responses are described next, and form the main body of the Results.

\section{Axial rotation}

The responses of a cell responding during axial rotation with a view of the testing chamber are illustrated in Figure 2, top. The firing rate for the cell was measured for a nonmovement period of between 2 and $4 \mathrm{sec}$, after which the monkey was rotated clockwise or counterclockwise through $360^{\circ}$ from a start position in the center of the test chamber, facing wall 3. The response of the cell was direction selective for counterclockwise rotation, in the sense that the evoked firing rate for counterclockwise rotation was approximately eight times that for clockwise rotation.

The responses of another cell are shown in peristimulus (or perimovement) rastergram form in Figure 3 . This cell responded primarily during clockwise and counterclockwise rotation (Fig. $3 A$ ); the cell showed little if any response during periods of nonmovement (compare Fig. 3, $A$, showing axial rotation, to $C$, in which the monkey was still); the cell responded rather less during periods of rotation with visual field occlusion (Fig. $3 B$ ). The peristimulus histogram shows that the cell responded rather more at the start of than later in the movement. 

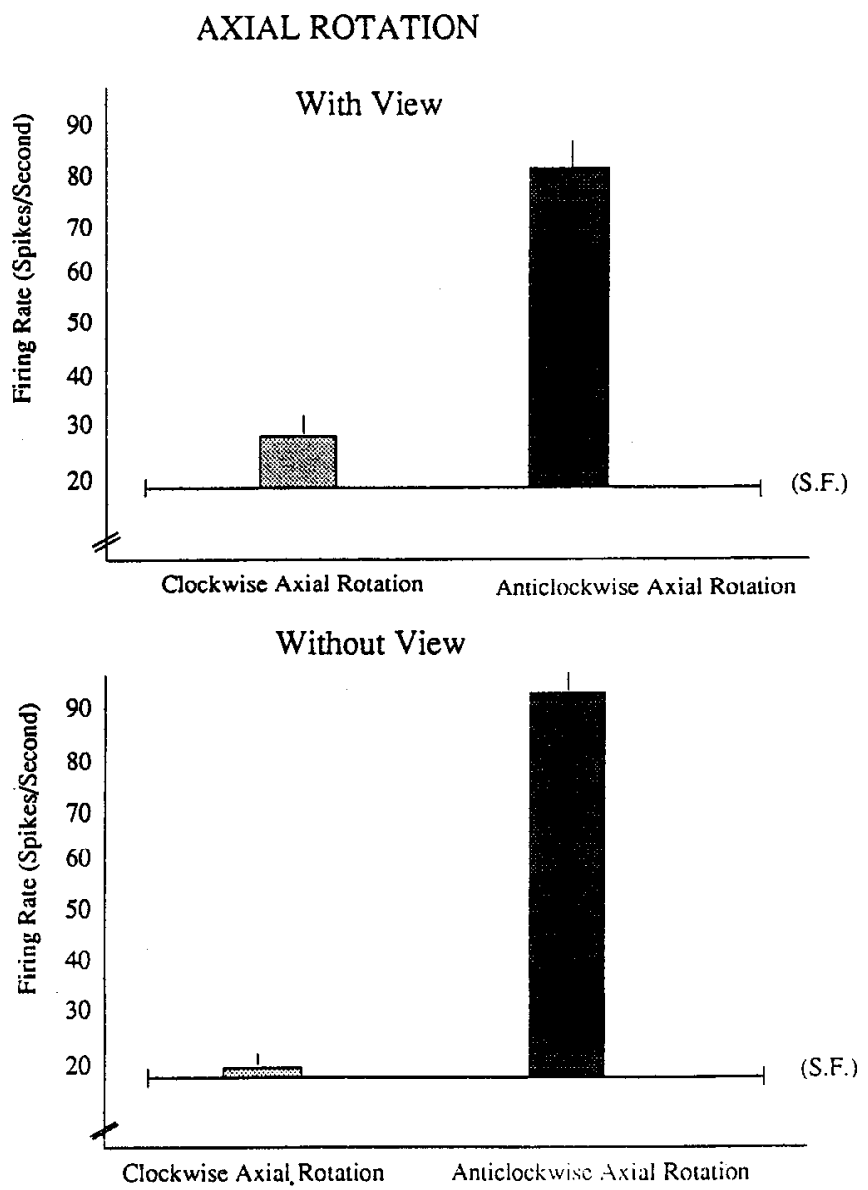

Figure 2. Top, The firing rate of a neuron with a direction-selective response during axial whole-body rotation. The mean and SE of the firing rate are shown. This was measured during the whole-body motion, including the acceleration, steady velocity, and deceleration phases. The baseline $(S . F$.$) is the firing rate of the neuron when the monkey was$ stationary in the test chamber. The dark shading indicates the conditions that were statistically significant from the baseline firing rate. These conventions are also used in the following figures. Bottom, The same neuron increased its firing rate during counterclockwise but not during clockwise axial rotation, while the visual field of the monkey was occluded.

Thirty-three of the cells tested responded to whole-body motion (rotation and translation); 13 of these cells responded to rotation only. Of the 13 that responded to rotation only, nine responded to both clockwise and counterclockwise rotation, two responded to clockwise rotation only, and two to counterclockwise rotation only.

\section{Linear motion}

Linear translation: forward and backward. Other cells responded to linear translation (forward and/or backward) and had smaller or no responses to axial rotation. The cell illustrated in Figure $4 i$ responded to linear translation, with an increase in firing rate during backward but not forward motion. The baseline firing rate shown in Figure $4 i$ is the firing rate when the monkey was not moving.

Another cell responded during linear translation by decreasing its firing rate from a spontaneous rate of $9.6 \pm 0.2 \mathrm{spikes} / \mathrm{sec}$ to $5.3 \pm 0.5$ spikes/sec during forward motion. In contrast, it decreased its firing rate to $4.2+0.5$ spikes/sec during backward linear translation. The cell did not respond to linear translation
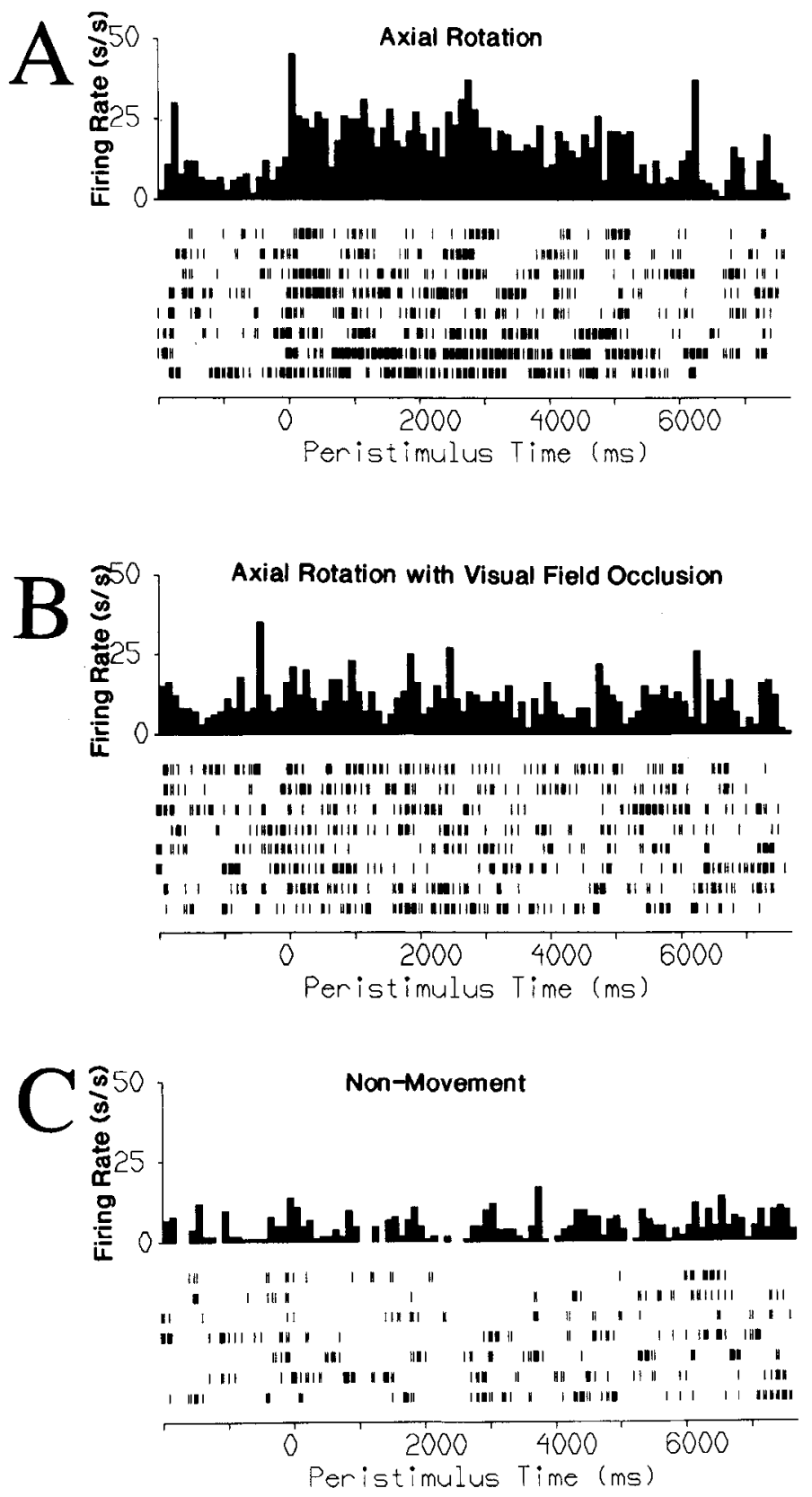

Figure 3. Peristimulus (or perimovement) rastergrams and firing rate histograms for a hippocampal cell that responded most during axial rotation under free-viewing conditions $(A)$, much less when the visual field was occluded $(B)$, and not at all during nonmovement $(C)$. The response of the cell during linear translation was not significantly different from that during periods of nonmovement (data not shown). The whole-body motion started at time 0 and stopped after $4.5 \mathrm{sec}$.

when the visual field was occluded (the rate increased by 1.3 spikes/sec); this cell therefore required input from the moving visual field during linear translation for its response. The cell did not respond during axial rotation, although the visual field was not occluded during this manipulation. Furthermore, the cell did not respond to randomly presented views of the walls of the environment while the monkey was seated at the center of the chamber. In the latter test the monkey was rotated to different orientations in random order and a firing rate count was made, as described above, for a $4-6$ sec period while the monkey faced each of the walls. Cells have been found that 

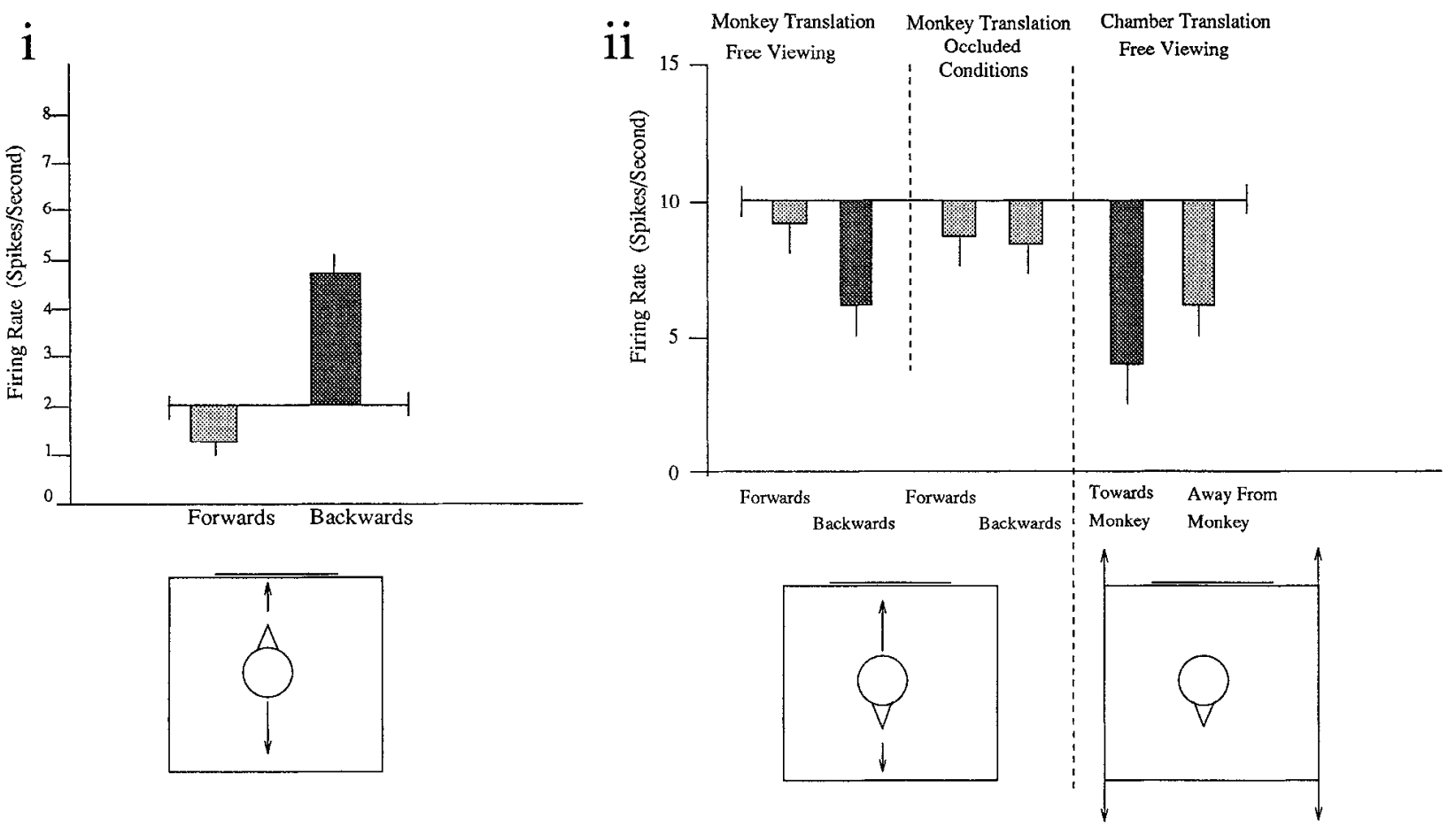

Figure 4. $i$, Activity of a neuron that increased its firing rate during backward linear translation, and decreased it during forward linear translation. ii. Activity of a neuron that decreased its firing rate during linear translation of the monkey away from wall 3 , and that decreased its firing rate during linear translation of the test chamber (wall 3) away from the monkey.

respond to such views of the test environment (see introductory remarks). This cell therefore responded only to linear translation under free-viewing conditions.

Lateral translation. It was also possible to test 10 cells with lateral translation, of which four responded to lateral translation. In no case was a cell found that responded to lateral translation only; if a cell responded to lateral translation it also responded to linear sagittal translation.

Twenty-nine of the cells tested responded to linear translation, with nine of the cells responding to linear translation only. Of the nine that responded to linear translation only, five cells responded to all linear movements, three to forward linear translation only, and one to backward linear translation only.

\section{Effects of occlusion of the visual field on the responses of cells responding to whole-body motion}

Obscuring the view the monkey had of the testing environment had no effect on the responses of some of the cells responding to whole-body motion. Data from such a cell are shown in the bottom of Figure 2, which indicates that the cell continued to have direction-selective responses to axial rotation even when the testing environment was obscured. The response of the cell was direction selective for counterclockwise rotation, in the sense that the evoked firing rate for counterclockwise rotation was approximately nine times that for clockwise rotation. This is an indication that its response could be due to vestibular (or possibly proprioceptive) input, and not to visual input. In contrast, the cell described below (see Fig. 5) is an example of a cell whose response properties are affected dramatically by visual field occlusion. In this case the cell requires a visual input for a response, and removal of the visual input through visual field occlusion removes the crucial input determining the response of the cell. It should be emphasized, however, that simply having a view of the test chamber walls (see Fig. 5) is not sufficient to drive the cell, as indicated by the view tests conducted on the cell. There were no significant differences in the response of the cell to views of the test chamber walls, and thus this cell was not "view responsive."

It was possible to test the responses of 20 cells in this way, and of these eight continued to respond with little or no diminution of response to whole-body motion when the visual field was obscured, and 12 showed little or no response to wholebody motion when the visual field was obscured.

\section{Effects of movement of the test environment}

Effects of rotation of the test chamber. Some cells responded when the test environment was moved. For example, the cell shown in Figure 5, left, responded when the cue-controlled test chamber was rotated around the monkey, while the monkey was stationary in the center of the test chamber initially facing wall 3. The response was a little greater to counterclockwise than to clockwise rotation (Fig. 5, left). Consistent with this being a visual response, it is shown in Figure 5, middle, that the response was absent during motion of the test chamber when the monkey's view of the test chamber was obscured by placing a mask on the front of the test chair and turning out the lights during chamber rotation. Rotation of the monkey did not affect the response of the cell (see Fig. 5, right). Translation of the monkey under free-viewing or visually occluded conditions (graphs not shown) did not affect the response of the cell.

Interestingly, the responses of the neuron shown in Figure 5, left, occurred when the visual field was moved and the monkey was stationary, but not when the monkey was rotated in the test chamber (Fig. 5, middle), even though this would induce visual motion cues. Thus, the responses of this cell appeared to occur to visual motion cues when they were not induced by body 


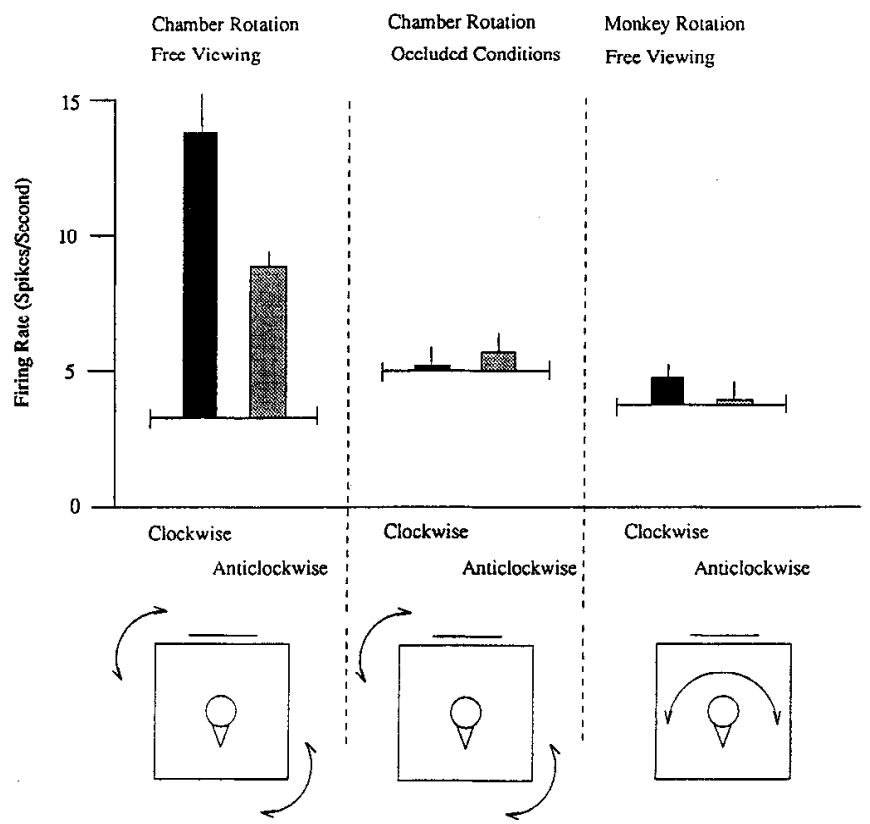

Figure 5. Responses of a neuron that increased its rate during rotation of the chamber when the monkey could see the chamber (left), but not in a control condition when the monkey could not see the chamber (middle). This neuron did not respond when the monkey was rotated in the chamber, even though he could see the chamber (right).

motion. (As noted in Materials and Methods, such a stimulus produces vection, and as noted in the Discussion, such visual information could be useful for navigation.)

Another cell whose response was affected by chamber rotation is shown in Figure 6. This cell responded to counterclockwise rotation of the test chamber (Fig. 6i), and also (in contrast to the previous cell) responded most during axial clockwise wholebody rotation of the monkey (Fig. 6iii). The cell thus had consistent responses in these two conditions, responding best when visual motion cues moved from the monkey's right to his left. The cell did not respond to chamber rotation when the visual field of the monkey was occluded (Fig. 6ii). (There were no significant differences between the firing rates of the cell in the two chamber motion conditions and the spontaneous rates measured before and after the chamber rotations (Fig. $6 i i)[F(3,16)$ $=2.45, p=0.09]$.) The cell also did not respond statistically significantly during axial rotation with the visual field of the monkey occluded (Fig. 6iv). The cell did not respond to linear translation (data not shown). The response of this cell was therefore generated by visual motion cues, regardless of whether they originated from whole-body rotation or chamber rotation.

It was possible to test the responses of 19 of the cells in this way, of which 10 cells responded to chamber movement. One cell responded to chamber rotation only and nine responded to both chamber rotation and rotation of the body. The responses of the other 10 cells were unaffected by rotation of the test chamber when this was conducted under free-viewing conditions, or when other possible stimuli were controlled for (e.g., auditory cues generated by chamber rotation that might have contributed to the observed responses; these would be much greater during chamber rotation compared to chair rotation).

Effects of translation of the test chamber. The response of a cell that responded more when the monkey was moving backward than forward in the test chamber is shown in Figure 4ii, left. It is shown in Figure 4ii, right, that the neuron had a cor-
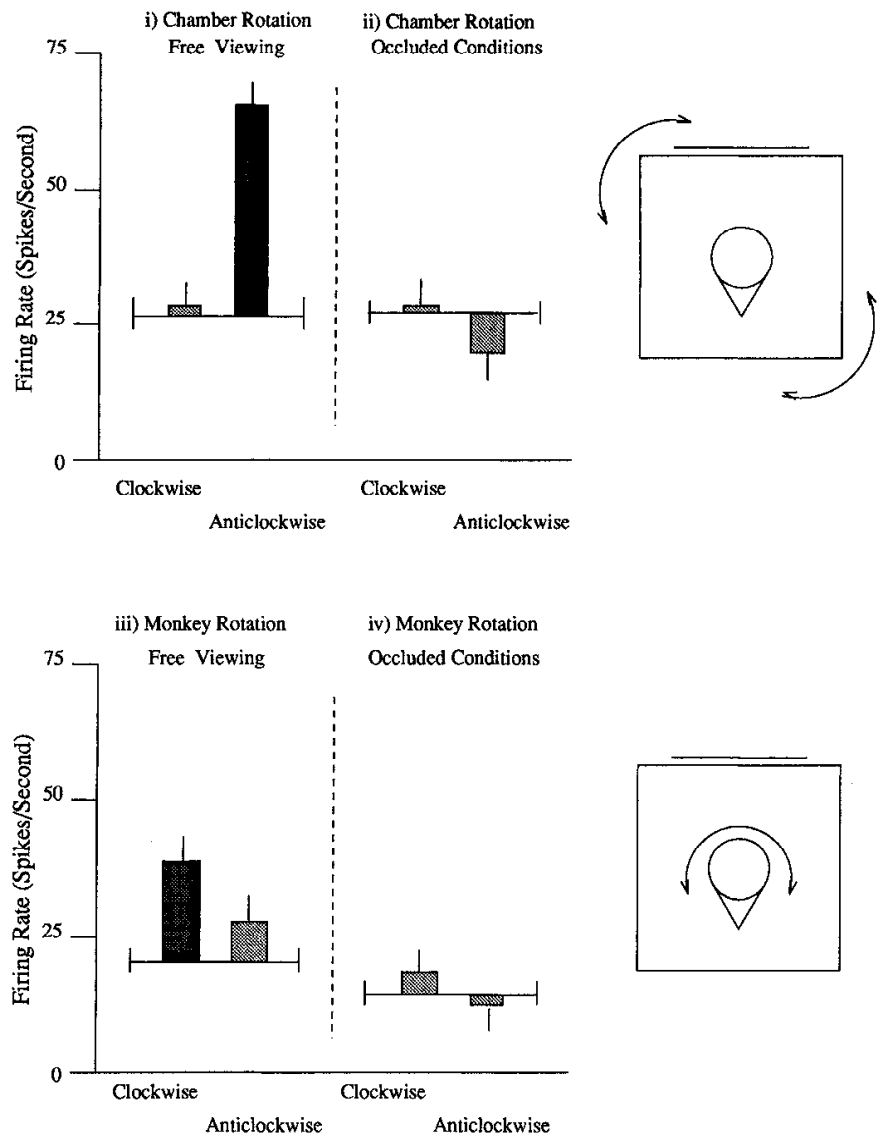

Figure 6. The response of a neuron that increased its firing rate during chamber rotation (i), but did not respond during chamber rotation during visually occluded conditions (ii). The cell also responded to whole-body rotation under free-viewing (iii) but not visually occluded conditions (iv).

responding response when the test chamber was moved; that is, the neuron responded more when the test chamber was moving away from the monkey's face than when moving toward it. The movements were in all cases linear translations of $1.5 \mathrm{~m}$. The cell had very little response when the monkey was moved in the dark, with his view of the chamber occluded (Fig. 4ii, middle).

It was possible to test the responses of five cells to linear movement of the test chamber, and of these three responded to translation of the test environment, showing that these cells could be influenced by visual motion signals.

\section{Cells responding to a combination of whole-body motion and environmental view}

The cell shown in Figure 7 responded when the monkey was moving along wall 2 of the test chamber, but not when he was moving along other walls. The cell did not respond at any time when the monkey was stationary, for example, when he was in the corners, or when he was looking at wall 2. During this experiment it was found that the boundaries of the region within which the cell responded during movement were at corners one and two. One cell of this type (which was sensitive to a particular view combined with whole-body motion for a particular wall of the test chamber) was found in the sample of cells tested. Thus, this cell did not respond to a view of wall 2 in the absence of motion while the monkey was looking at wall 2 , and therefore 


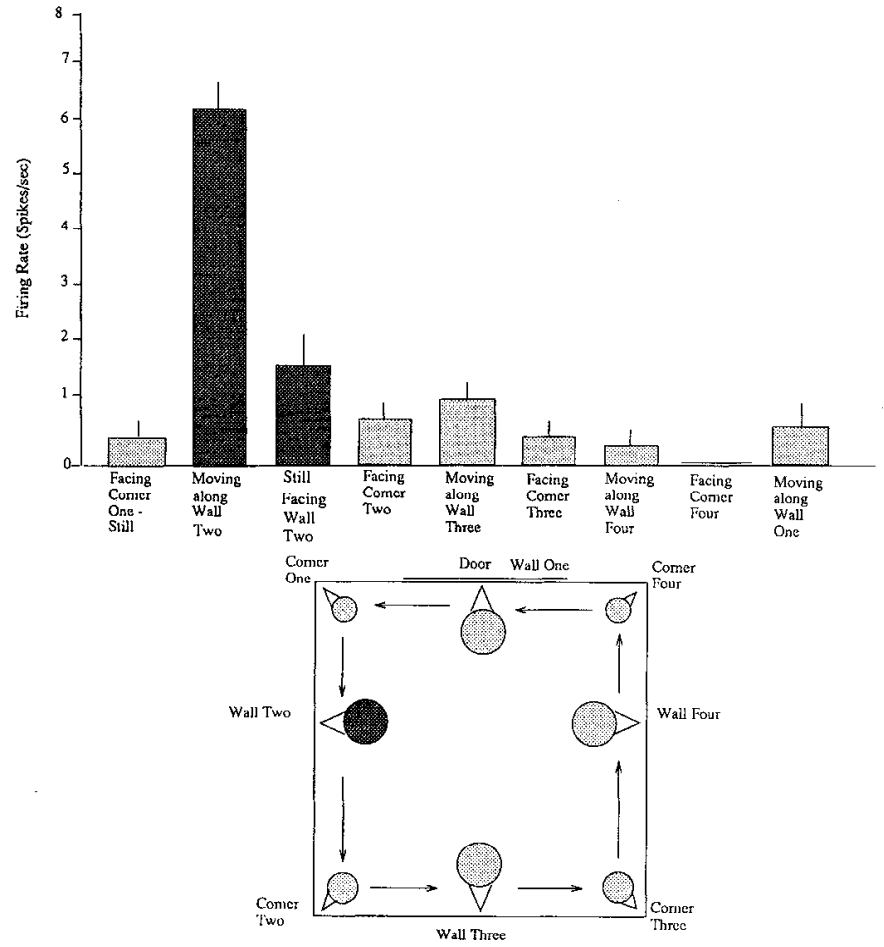

Figure 7. This neuron responded when the monkey moved along wall 2 of the test chamber, but not when he moved along any other wall, or when he was stationary.

the cell cannot be described as being sensitive to views alone. Such a cell could respond to a combination of whole-body motion with a view of the environment (or possibly with a place in the environment).

Of the 45 cells with whole-body motion-related activity tested, two had responses of this type.

\section{Body motion toward a place}

One cell has been found that responded best when the monkey was moved toward the door of the test chamber, regardless of the orientation of the monkey in the chamber when moving toward that place. The monkey was moved forward, backward, left side, and right side toward the door of the test chamber. The cell was tested by taking a measure of the spontaneous firing rate for a $5 \mathrm{sec}$ period, and then taking another measure while the monkey was moved in a particular direction. These directions were forward (Fig. 8i), backward (Fig. 8ii), leftward (Fig. 8iii), or rightward (Fig. 8iv) to the door. It was found that there was no significant difference between the firing rate counts for the periods when the monkey was stationary in different places, including periods when he was facing the door and was close to it or was at the other side of the test chamber (data not shown). Thus, there was no significant place-related firing in the absence of whole-body motion toward that place.

It can be seen that for all of these manipulations the cell responded best when the direction of movement was toward the door. This is true even when the monkey was moved backward toward the door of the test chamber, although the response of the cell is somewhat lower than when the monkey faces the door directly. The cell did not respond when the animal was positioned at, but not moving toward, the door (data not shown). The cell also did not respond to axial rotation or to static views of the door from the center of the chamber (data not shown).
COMBINATION OF BODY MOTION WITH PLACE
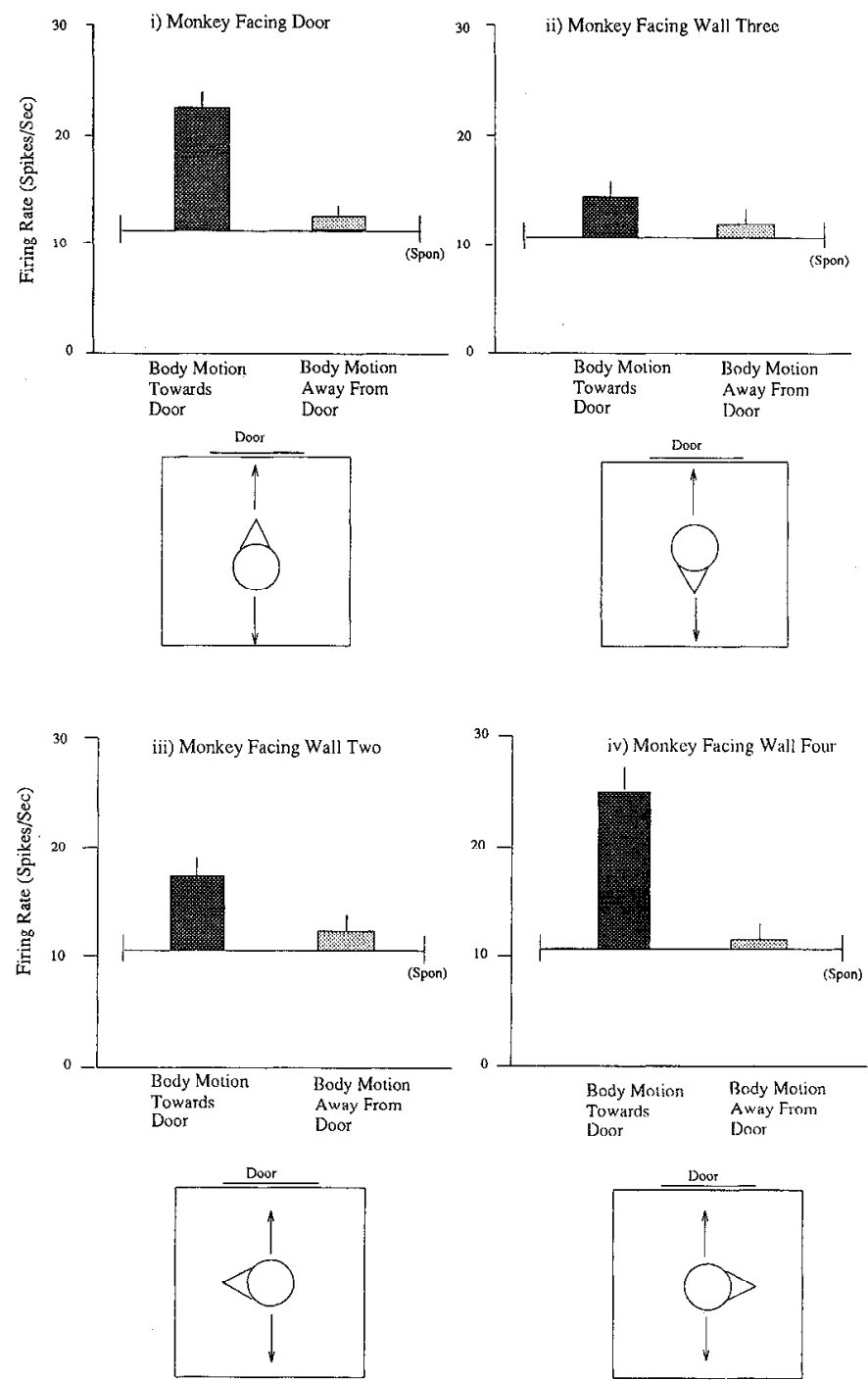

Figure 8. This neuron responded most when the monkey was moving toward the door of the test chamber, relatively independently of the direction in which the monkey was facing during the movement. The cell did not respond when the monkey was still, regardless of which way he was facing.

\section{Recording sites}

The recording sites, based on reconstructions using the microlesions made through the recording microelectrode tips, and the $\mathrm{x}$-radiographs, are shown in Figure 9.

The cells described here were in at least the majority of cases likely to be hippocampal pyramidal cells for the following reasons. First, the reconstruction of the recording sites based on microlesions made through the recording microelectrodes and the $\mathrm{x}$-radiographs showed that some of the cells were in the pyramidal cell region. Second, the spikes recorded were of large amplitude (as shown in Fig. 10i), and were comparable to neocortical pyramidal cells. Third, the spontaneous firing rates of the cells were relatively low, with a mean spontaneous rate of $12.9 \mathrm{spikes} / \mathrm{sec}$ (and an SE of $1.8 \mathrm{spikes} / \mathrm{sec}$ ). The distribution of the spontaneous firing rates of the cells is shown in Figure $10 i i$. 


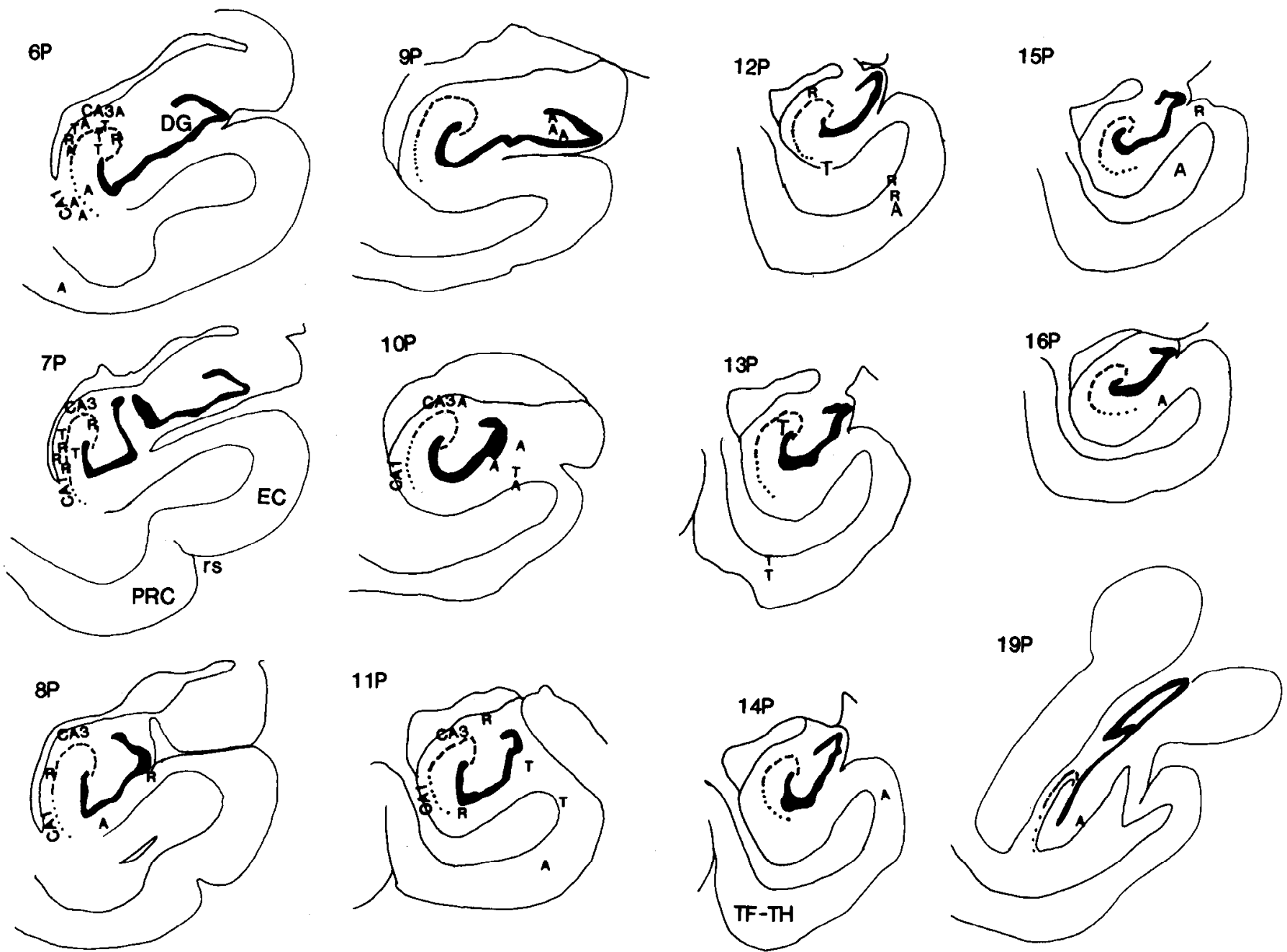

Figure 9. Recording sites. The coronal sections are at different distances in millimeters posterior $(P)$ to the sphenoid reference (see text). The dentate is indicated by the thick dark line; the CA3 and CA1 pyramidal cells by the dotted line. $R$, cell responding to whole-body rotation; $T$, cell responding to linear translation; $A$, cell responding to axial rotation or linear translation. $E C$, entorhinal cortex; $D G$, dentate gyrus; $P R C$, perirhinal cortex; $r s$, rhinal sulcus; $T F-T H$, areas of the parahippocampal gyrus.

\section{Discussion}

These results show that there are neurons in the primate hippocampus that are modulated by whole-body motion. The cells in this population provide information about the type of motion, because some cells respond with direction selectivity (e.g., to forward but not backward motion, or to clockwise but not to counterclockwise motion), and because some cells respond to linear not axial motion, and vice versa. The responses of the population of neurons did not just reflect arousal or nonspecific effects that might have been produced by the whole-body motion, because neuronal responses that reflected the direction of the movement were found, because different neurons had responses related to different types of motion, and because neurons did not respond to arousal when it was produced in the absence of whole-body motion.

The discovery of these cells links immediately to modern ideas about how spatial navigation may be performed by animals including humans. Gallistel (1990) has noted that navigation may be performed by organisms that can compute bearing to landmarks, and distance traveled between landmarks.
Part of the significance of the results described here is that we have shown that information about body motion does reach a part of the brain, the hippocampus, which could be involved in spatial navigation. The hippocampus may use this information to perform the necessary spatial computations, or it may act as a memory for spatial and other information to assist spatial computation (see below).

Our findings differ from earlier investigations in nonhuman primates in that we specifically investigated the responses of hippocampal neurons during periods of whole-body motion (cf. Tamura et al., 1990, 1992a,b), and found that there is a population that responds specifically in relation to whole-body motion. The majority ( 42 of 45 ) of the cells described here responded only in relation to whole-body motion, independently of the particular view the monkey had of the environment, or where the monkey was. A small proportion ( 3 of 45 ) responded to a combination of whole-body motion and either view or place. The issue of how places in the environment and views of the environment are represented in the primate hippocampus is a topic of separate investigations (Ono et al., 1993; Rolls and O’Mara, 1993). 

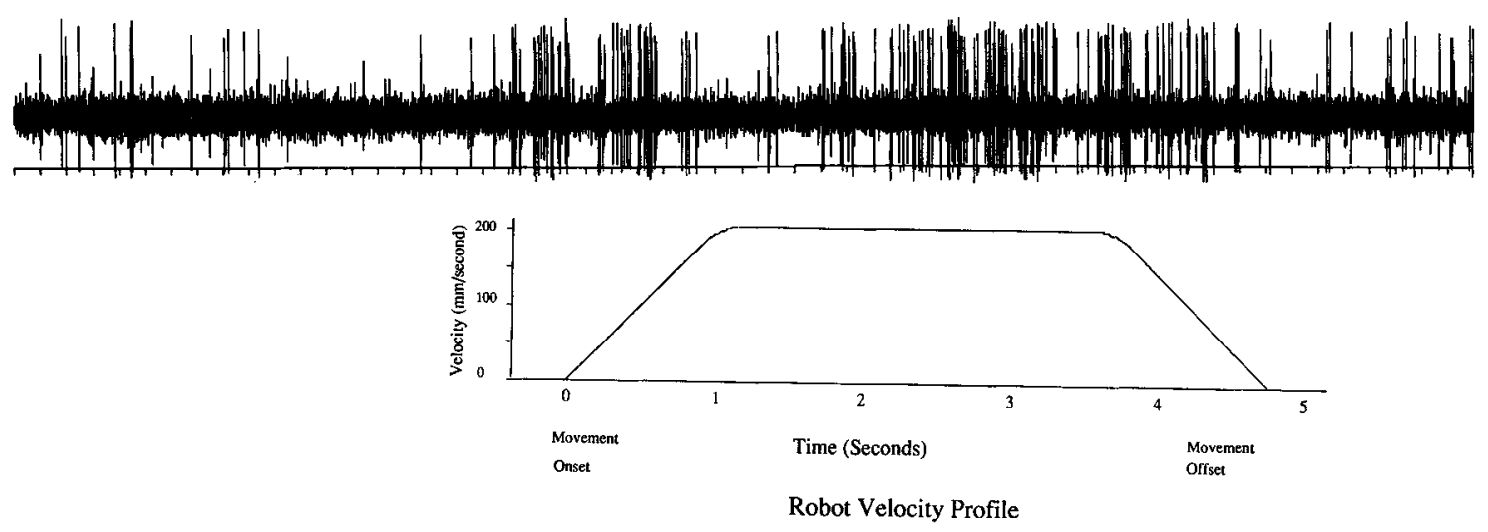

ii) Spontaneous Firing Rate Distribution

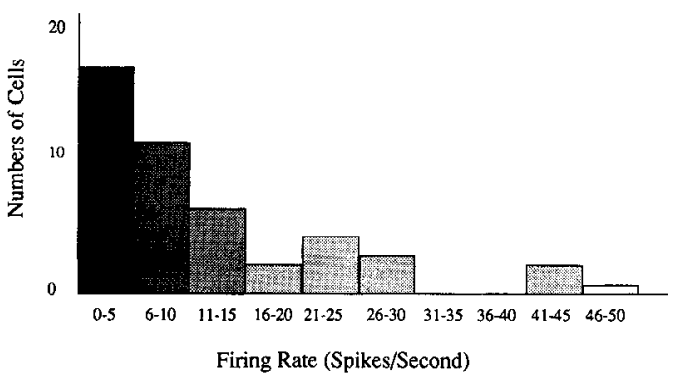

Figure 10. $i$, Spike waveforms of a cell responsive to linear translation. The time calibration ticks are 100 msec apart. $i i$, The standard velocity profile used for linear translation. $i i i$, Distribution of spontaneous firing rates of these cells.

\section{Vestibular and visual influences on the primate hippocampus}

The responses of many of the neurons appeared to reflect vestibular inputs, as the responses of a reasonable proportion ( $40 \%$ of the cells tested with occlusion) still occurred when the monkey could not see the visual field during the whole-body motion (which, as noted below, also controls for the possible contribution of eye movements). Although proprioceptive information could possibly have played a role in some of the ncuronal responses, we believe that it is unlikely to have made much contribution in this particular testing situation in which the monkey was sitting in the chair with his head still. Moreover, the cells described here did not respond if the monkey was not undergoing whole-body motion, but was moving parts of his body, or if parts of his body were touched. Further evidence that some of these cells responded in relation to vestibular or visual inputs, rather than to movements including locomotor movements being made, was that in our study, the monkey did not actively locomote, but instead was moved while sitting. Comparably, in rats, locomotion is not necessary for the responses of head-direction cells (Taube et al., 1990a,b) and place cells (Sharp et al., 1990), which are activated when rats are hand held and moved passively into the appropriate locations in test chambers (provided that they are not bound tightly; Foster et al., 1989). We also note that it would be of interest in future studies, now that these neurons have been discovered, to measure eye movements during the recordings, and to examine their relation to the hippocampal neuronal activity. Eye movements occur during whole-body motion and are produced by vestibular stimulation, but are likely to differ in the dark as compared to the light, at least during linear translation. Moreover, eye movements made when the monkey was stationary in the light were not noted to produce responses of the neurons described here, which in any case had tonic responses. However, it will be of interest to analyze this further with the search coil technique.

Vestibular information about whole-body motion may reach the primate hippocampus via the parietal cortex, specifically through the vestibular cortical area called the parietoinsular vestibular cortex (PIVC) (Grusser et al., 1990a,b; Guldin et al., 1993; see Wiener and Berthoz, 1993). The majority of the neurons in this area respond to head angular motion. Interestingly, no neurons have yet been described in the PIVC that respond to linear motion. Many neurons in this area also respond to visual and somatosensory information about head movement. In addition, there are many visual cortical areas such as MT, MST, and parietal cortex in which neurons are tuned to optic flow (Albright, 1984; Maunsell and Van Essen, 1984; Colby et al., 1993). Moreover, the parietal cortex has strong connections (via the parahippocampal gyrus) to the hippocampus (Van Hoesen, 1982; Cavada and Goldman-Rakic, 1989). Visual information from the ventral visual stream (Ungerleider and Mishkin, 1982) may also reach the hippocampus from the inferior temporal cortex via the entorhinal cortex (Felleman and Van Essen, 1991).

Some of the neurons of the hippocampus in this study were influenced by visual stimuli, and in particular by the movement 
(rotation/translation) of the walls of the testing chamber (see, e.g., Fig. 5). This was shown by the smaller responses some whole-body motion neurons showed when the visual field was occluded ( $60 \%$ of the sample tested with occlusion), and by the finding that some of these neurons responded when the testing chamber was moved but the monkey was still. Some neurons had direction-selective responses that were consistent with the hypothesis that they received appropriate direction-selective inputs from both vestibular and visual inputs. This convergence is not unexpected; in the vestibular nucleus, for example, the first vestibular relay in the CNS, there are visual influences on some neurons (Yoshida et al., 1981; Berthoz et al., 1989). The convergence is useful, because a combination of the visual and vestibular signals may help navigation, for example, and because the visual signals may be used to set the gain in the vestibular pathways.

One neuron responded to rotation of the test chamber walls when this was not associated with the corresponding wholebody motion. The ability to respond to such information is important, for somctimes at lcast part of the visual world can move in the absence of whole-body motion, and under some circumstances whole-body motion cannot be signaled only by vestibular inputs, for example, during long periods of constant velocity motion when the vestibular signals (which reflect acceleration) are no longer present (e.g., in a car or train, or when flying).

The findings thus show that a description of information about whole-body motion including information derived from visual and vestibular systems is reflected in the activity of this population of hippocampal neurons. Although as far as we know studies have not been performed to investigate whether motion of the visual environment influences hippocampal neurons in the rat, it has been shown that visual signals may influence some cells with place-related firing (e.g., Quirk et al., 1990).

\section{Possible contributions of whole-body motion cells to spatial navigation}

Whole-body motion (and also views of the environment) may be useful to represent in an episodic memory system implemented in the hippocampus (Rolls, 1989a,b; Treves and Rolls, 1993). The responses of the population of neurons described here would provide very useful information about recent motion of the body. For example, an episodic memory may include the fact that whole-body motion had been forward for $5 \mathrm{sec}$ at a particular velocity, that the direction was unchanged from the starting direction, and that a particular part of environmental space (signaled by the "space" or "view" neurons) (Rolls and O'Mara, 1993) had been visible. Another such episodic memory may be that a right turn had then been made, and that another view of the environment had become visible. Such episodic memories that included information about whole-body motion would be invaluablc for navigation (and possibly "path integration") in small environments (in which memory of a set of whole-body motions, and visible cues, would be appropriate for computing further trajectories, e.g., back to the origin) (Wiener and Berthoz, 1993). The relatively low proportion $(9.9 \%)$ of cells responding to whole-body motion, and the fact that the cells tended to have different responses to each other, is consistent with other recording studies in monkeys (Cahusac et al., 1989; Miyashita et al., 1989), and is consistent with the hypothesis that an autoassociative memory is implemented in the hippocampus, for sparse representations increase the number of memories that can be stored in these networks (Rolls, 1989a, 1991; Treves and Rolls, 1991, 1994).

An alternative hypothesis is that the responses of these wholebody motion ncurons reflect the operation of a spatial computation performed by the hippocampus itself, for example, given the current place of the animal, and the desired place, what body turns to make (e.g., O'Keefe, 1990). Arguments for the different hypotheses of hippocampal function are considered elsewhere (Rolls, 1989a,b, 1991; McNaughton and Nadel, 1990; O'Keefe, 1990; Treves and Rolls, 1994).

\section{Comparison of findings in rats and monkeys}

The locations of the whole-body motion cells recorded in the monkey (see Fig. 9) were in the hippocampal pyramidal fields and the parahippocampal gyrus. The cells recorded in the hippocampus itself were probably pyramidal cells, as discussed above. In the monkey, as noted elsewhere (Rolls et al., 1989), clear theta-like cells are not found, and indeed the only suggestion of theta itself in monkeys was obtained under urethane anesthesia (Stewart and Fox, 1991). The firing rates of the neurons described above are consistent with those of the cells described by Ono and his colleagues, which had for example a mean spontaneous firing rate of 6.5 spikes/sec with an SD of 6.2 spikes/sec, and evoked firing rate in the range of 4-70 spikes/ sec (Tamura et al., 1990, 1992a,b). The spatial cells described by Rolls and colleagues also fall within these ranges (e.g., Rolls et al., 1989; Feigenbaum and Rolls, 1991), as do the hippocampal units recorded during various memory tasks by Wilson et al. (1990) and Brown (1991). The hippocampal units described in the studies on humans by Wilson et al. (1991) have spiking activity ranging from about 1 spike/sec to about 150 spikes/sec. Such studies have been carried out in epileptic subjects, in whom hippocampal unit activity may be somewhat abnormal. For comparison, hippocampal pyramidal place cells in the rat typically have a low spontaneous firing rate $(<1 \mathrm{spike} / \mathrm{sec})$ when outside their place field, which may rise to $12-15$ spikes/sec when in their place field (e.g., O'Keefe and Nadel, 1978; Quirk et al., 1990).

In rats, cells responding when rats move in an environment have been described. For example, McNaughton et al. (1983) described place cells that responded when a rat was moving in one direction along the arm of an eight-arm radial maze, but not in the other direction (see also Breese el al., 1989; Wiener et al., 1989). At least some of these cells respond when the rat is not moving in the place, so that they are not the type of wholebody motion cell described here, most of which responded independently of where the monkey was. Theta cells in the rat tend to fire more during locomotion than when the rat is still (e.g., Christian and Deadwyler, 1986), but these cells may nevertheless fire most when the rat is locomoting through particular places (Kubie et al., 1990). The testing methods used so far in the rat have not been equivalent to those used here for primates, and it is partly for this reason that we do not know whether there are cells in the rat of the type described here that have activity that can be related specifically to the direction of wholebody motion in the absence of visual inputs when the animal is not actively making the movement.

During active movement, it is not clear whether a neuronal response related to whole-body motion occurs because it is part of a system that produces the movement, or part of a system such as the vestibular system that provides information about the whole-body movements being made (cf. Castro et al., 1989). 
It is likely that there is a vestibular input to the rat hippocampus, for the spatial fields of rats that cannot see or hear the environment rotate with a maze when the maze is rotated with the rat placed on it (and the spatial response is lost when the rat is repeatedly and rapidly turned) (Hill and Best, 1981). A similar effect is observed in rats with fornix lesions, which must rely on vestibular signals in a spatial discrimination task (Matthews et al., 1988). Further, the responses of head direction cells in the rat postsubiculum can probably be influenced by vestibular, as well as by visual, inputs (Taube et al., 1990a,b). It would certainly be useful to investigate whether there are whole-body motion cells of the type described here in the rat as well as in the primate hippocampus, in view of their potential utility in spatial navigation generally.

\section{References}

Aggleton JP, Passingham RE (1981) Stereotaxic surgery under x-ray guidance in the rhesus monkey, with special reference to the amygdala. Exp Brain Res 44:271-276.

Albright TD (1984) Direction and orientation selectivity of neurons in visual area MT of the macaque. J Neurophysiol 52:1106-1130.

Andersen RA (1987) Inferior parietal lobule function in spatial perception and visuomotor integration. Handbook of physiology, Sect 1, The nervous system, Vol V, Higher functions of the brain, $\mathrm{Pt} 2$, pp 483-518. Bethesda, MD: American Physiological Society.

Barnes CA (1988) Spatial learning and memory processes: the search for their neurobiological mechanisms in the rat. Trends Neurosci 11: 163-169.

Beritoff JS (1965) Neural mechanisms of higher vertebrate behavior. New York: Brown.

Berthoz A, Droulez J, Vidal PP, Yoshida K (1989) Neural correlates of horizontal vestibulo-ocular reflex cancellation during rapid eye movements in the cat. J Physiol (Lond) 419:717-751.

Breese CR, Hampson RE, Deadwyler SA (1989) Hippocampal place cells: stereotypy and plasticity. J Neurosci 9:1097-1111.

Brown MW (1990) Why does the cortex have a hippocampus? In: Learning and computational neuroscience: foundations of adaptive networks (Gabriel M, Moore JW, eds).

Cahusac PMB, Miyashita Y, Rolls ET (1989a) Responses of hippocampal neurons in the monkey related to delayed spatial response and object-place memory tasks. Behav Brain Res 33:229-240.

Cavada C, Goldman-Rakic PS (1989) Posterior parietal cortex in rhesus monkey: I. Parcellation of areas based on distinctive limbic and sensory corticocortical connections. J Comp Neurol 287:393-421.

Christian EP, Deadwyler SA (1986) Behavioral functions and hippocampal cell types: evidence for two overlapping populations. J Neurophysiol 55:331-348.

Colby CL, Duhamel JR, Goldberg MC (1993) Ventral intraparietal area of the macaque: anatomic location and visual response properties. J Neurophysiol 69:902-914.

Etienne AS, Maurer R, Saucy F (1988) Limitations in the assessment of path dependent information. Behaviour 106:81-111.

Feigenbaum JD, Rolls ET (1991) Allocentric and egocentric spatial information processing in the hippocampal formation of the behaving primate. Psychobiology 19:21-40.

Felleman DJ, van Essen DC (1991) Distributed hierarchical processing in the primate cerebral cortex. Cereb Cortex 1:1-47.

Foster TC, Castro CA, McNaughton BL (1988) Spatial selectivity of rat hippocampal neurons: dependence on preparedness for movement. Science 244:1580-1582.

Gaffan D, Harrison S (1988) A comparison of the effects of fornix section and sulcus principalis ablation upon spatial learning by monkeys. Behav Brain Res 31:207-220.

Gaffan D, Saunders RC (1985) Running recognition of configural stimuli by fornix transected monkeys. Q J Exp Psychol 37B:61-71.

Gaffan D, Weiskrantz L (1980) Recency effects and lesion effects in delayed non-matching to randomly baited samples by monkeys. Brain Res 196:373-386.

Gaffan D, Saunders RC, Gaffan EA, Harrison S, Shields C, Owen MJ (1984a) Effects of fornix transection upon associative memory in monkeys: role of the hippocampus in learned action. Q J Exp Psychol 26B:173-221.
Gaffan D, Gaffan EA, Harrison S (1984b) Effects of fornix transection on spontaneous and trained non-matching by monkeys. Q J Exp Psychol 36B:285-303.

Grusser OJ, Pause M, Schreiter U (1990a) Localisation and responses of neurons in the parieto-insular vestibular cortex of awake monkeys (Macaca fascicularis). J Physiol (Lond) 430:537-557.

Grusser OJ, Pause M, Schreiter U (1990b) Vestibular neurons in the parieto-insular cortex of monkeys (Macaca fascicularis): visual and neck receptor responses. J Physiol (Lond) 430:559-583.

Guldin WO, Akbarian S, Grusser OJ (1992) Cortico-cortical connections and cytoarchitectonics of the primate vestibular cortex: a study in the squirrel monkey. J Comp Neurol 326:375-401.

Hill AJ, Best PJ (1981) Effect of deafness and blindness on the spatial correlates of hippocampal unit activity in the rat. Exp Neurol 74: 204-217.

Kubie JL, Muller RU, Bostock E (1990) Spatial firing properties of hippocampal theta cells. J Neurosci 10:1110-1123.

Matthews BL, Campbell KA, Deadwyler SA (1988) Rotational stimulation disrupts spatial learning in fornix-lesioned rats. Behav Neurosci $102: 35-42$.

Maunsell JHR, Van Essen DC (1983) Functional properties of neurons in middle temporal visual area of the macaque monkey. I. Selectivity for stimulus direction, speed and orientation. J Neurophysiol 49: 1127-1147.

McNaughton BL, Barnes CA, O'Keefe J (1983) The contributions of position, direction, and velocity to single unit activity in the hippocampus of freely-moving rats. Exp Brain Res 52:41-49.

Merrill EG, Ainsworth A (1972) Glass-coated platinum-plated tungsten microelectrodes. Med Biol Eng 10:662-672.

Miller S, Pulegal M, Abraham L (1983) Vestibular involvement in a passive transport and return task. Physiol Psychol 11:1-10.

Milner B (1972) Disorders of learning and memory after temporal lobe lesions in human. Clin Neurosurg 19:421-446.

Mittelstaedt H, Mittelstaedt M-L (1982) Homing by path integration. In: Avian navigation (Papi H, Wallraff G, eds), pp 290-297. Berlin: Springer.

Mittelstaedt M-L, Glasauer S (1991) Idiothetic navigation in gerbils and humans. Zool J Physiol 95:427-435.

Miyashita Y, Rolls ET, Cahusac PMB, Niki H, Feigenbaum JD (1989) Activity of hippocampal formation neurons in the monkey related to a conditional spatial response task. J Neurophysiol 61:669-678.

O'Keefe J (1979) A review of the hippocampal place cells. Prog Neurobiol 13:419-439.

O'Keefe J (1990) A computational theory of the cognitive map. Prog Brain Res 83:301-312.

O'Keefe J, Nadel L (1978) The hippocampus as a cognitive map. Oxford: Clarendon.

O'Mara SM, Toth TI, Rolls ET (1991) Are there place cells in the primate hippocampus? Eur J Neurosci S4:59.

O'Mara SM, Berthoz A, Rolls ET (1992a) Spatial representation in the primate hippocampus. Neurosci Lett $S 42: 6$.

O'Mara SM, Rolls ET, Berthoz A, Walsh V (1992b) Space, place and the primate hippocampus. Eur J Neurosci S5:285.

O'Mara SM, Rolls ET, Berthoz A, Walsh V (1992c) Whole-body motion cells in the primate hippocampus. Soc Neurosci Abstr 18:207.

Ono T, Nakamura K, Nishijo H, Eifuku S (1993) Monkey hippocampal neurons related to spatial and non-spatial functions. J Neurophysiol 70:1516-1529.

Parkinson JK, Murray EA, Mishkin M (1988) A selective mnemonic role for the hippocampus in monkeys: memory for the location of objects. J Neurosci 8:4159-4167.

Petrides M (1985) Deficits on conditional associative-learning tasks after frontal- and temporal-lobe lesions in human. Neuropsychologia 23:601-614.

Potegal M (1982) Vestibular and neostriatal contribution to spatial orientation. In: Spatial abilities: development and physiological foundations (Potegal M, ed), pp 361-387. New York: Academic.

Quirk GS, Muller RU, Kubie JL (1990) The firing of hippocampal place cells in the dark depends on the rat's recent experience. $J$ Neu rosci 10:2008-2017.

Rolls ET (1989a) Functions of neuronal networks in the hippocampus and neocortex in memory. In: Neural models of plasticity: experimental and theoretical approaches (Byrne JH, Berry WO, eds), pp 240-265. San Diego: Academic.

Rolls ET (1989b) The representation and storage of information in neuronal networks in the primate cerebral cortex and hippocampus. 
In: The computing neuron (Durbin $R$, Miall $C$, Mitchison $G$, eds), pp 125-159. Wokingham, UK: Addison-Wesley.

Rolls ET (1990) Functions of the primate hippocampus in spatial processing and memory. In: Neurobiology of comparative cognition (Olton DS, Kesner RP, eds), pp 339-362. Hillsdale, NJ: Erlbaum.

Rolls ET, O'Mara SM (1991) Are there place cells in the primate hippocampus? Soc Neurosci Abstr 17:1101.

Rolls ET, O'Mara SM (1993) Neurophysiological and theoretical analysis of how the hippocampus functions in memory. In: Brain mechanisms of perception and memory: from neuron to behavior (Ono $\mathrm{T}$, Squire LR, Raichle ME, Perrett DI, Fukuda M, eds), pp 276-300. New York: Oxford UP.

Rolls ET, Burton MJ, Mora F (1976) Hypothalamic neuronal responses associated with the sight of food. Brain Res 111:53-66.

Rolls ET, Sanghera MK, Roper-Hall A (1979) The latency of activation of neurones in the lateral hypothalamus and substantia innominata during feeding in the monkey. Brain Res 164:121-135.

Rolls ET, Miyashita Y, Cahusac PMB, Kesner RP, Niki H, Feigenbaum J, Bach L (1989) Hippocampal neurons in the monkey with activity related to the place in which a stimulus is shown. J Neurosci 9:18351845.

Rupniak NMJ, Gaffan D (1987) Monkey hippocampus and learning about spatially directed movements. J Neurosci 7:2331-2337.

Sakata $H$ (1985) The parietal association cortex: neurophysiology. In: The scientific basis of clinical neurology (Swash M, Kennard C, eds), pp 225-236. London: Churchill Livingstone.

Scoville WB, Milner B (1957) Loss of recent memory after bilateral hippocampal lesions. J Neurol Neurosurg Psychiatry 20:11-21.

Sharp PE, Muller RU, Kubie JL (1990) Firing properties of cells in a visually symmetric environment: contributions of mnemonic processes. J Neurosci 10:2008-2017.

Smith ML, Milner B (1981) The role of the right hippocampus in the recall of spatial location. Neuropsychologia 19:781-793.

Stewart M, Fox SE (1991) Hippocampal theta activity in monkeys. Brain Res 538:59-63.

Squire LR (1992) Memory and the hippocampus: a synthesis from findings from rats, monkeys and humans. Psychol Rev 99:195-231.

Tamura R, Ono T, Fukuda M, Nakamura K (1990) Recognition of egocentric and allocentric visual and auditory space by neurons in the hippocampus of monkeys. Neurosci Lett 109:293-298.

Tamura R, Ono T, Fukuda M, Nakamura K (1992a) Monkey hip- pocampal neuron responses to complex sensory stimulation during object discrimination. Hippocampus 2:287-306.

Tamura R, Ono T, Fukuda M, Nakamura K (1992b) Spatial responsiveness of monkey hippocampal neurons to various visual and auditory stimuli. Hippocampus 2:307-322.

Taube JS, Muller RU, Ranck JB (1990a) Head direction cells recorded from the postsubiculum in freely moving rats. I. Description and quantitative analysis. J Neurosci 10:420-435.

Taube JS, Muller RU, Ranck JB (1990b) Head direction cells recorded from the postsubiculum in freely moving rats. II. Effects of environmental manipulations. J Neurosci 10:436-447.

Treves A, Rolls ET (1991) What determines the capacity of autoassociative memories in the brain? Network 2:371-397.

Treves A, Rolls ET (1994) A computational analysis of the role of the hippocampus in memory. Hippocampus, in press.

Ungerleider L, Mishkin M (1982) Two visual systems. In: Analysis of visual behavior (Ingle DG, Goodale MA, Mansfield RJQ, eds). Cambridge, MA: MIT Press.

Van Hoesen GW (1982) The parahippocampal gyrus. New observations regarding its cortical connections in the monkey. Trends Neurosci 5:345-350.

Wiener SI, Berthoz A (1993) Vestibular contributions during navigation. In: Multisensory control of movement (Berthoz A, ed). London: Oxford UP.

Wiener SI, Paul CA, Eichenbaum H (1989) Spatial and behavioral correlates of hippocampal unit activity. J Neurosci 9:2737-2763.

Wilson CL, Isokawa M, Babb TL, Crandell PH, Levesque M, Engel J (1991) Functional connections in the human temporal lobe. II. Evidence for a loss of functional linkage between contralateral limbic structures. Exp Brain Res 85:174-187.

Wilson FAW, Riches IP, Brown MW (1990) Hippocampus and medial temporal cortex: neuronal activity related to behavioral responses during performance of memory tasks by primates. Behav Brain Res 40:7-28.

Yoshida K, Berthoz A, Vidal PP, McCrea RA (1981) Eye movement related activity of identified second order vestibular neurons in the cat. In: Progress in oculomotor research (Fuchs A, Becker W, eds), pp 371-378. Amsterdam: Elsevier.

Young $L$ (1984) Perception of the body in space. Handbook of physiology, Vol 14, Sensory processes. Bethesda, MD: American Physiological Society. 